\title{
Viewpoint: Triumph of the city
}

\section{Edward Glaeser}

\section{Harvard University}

Editor's note: The inaugural meeting of the World Symposium on Transport and Land Use Research (WSTLUR) was held in Whistler, British Columbia, July 28-30, 2011. The conference brought together academics and practitioners at the intersection of economics, planning, and engineering in the fields of transport and land use.

In addition to presentations based on rigorously peer-reviewed papers, the conference included a plenary presentation from Ed Glaeser, the Fred and Eleanor Glimp Professor of Economics with the Department of Economics, Harvard University, and author of the book Triumph of the City. Following are excerpts from Glaeser's keynote address.

I really couldn't be more honored to be here. I know of few areas where there is more need for the cogent light and clear thinking of research than transportation, where the dollars involved are huge, where the impact on human life is tremendous, and yet where it is so easy for some combination of politics and wishful thinking to dominate discourse in this area.

The prevailing story of [America in] the last 30 years has been one of increasing consolidation of the population, particularly around the dense metropolitan areas that are so productive. Indeed, the connection between density, income, and population growth shouldn't be a surprise; we've had a very strong tendency over the past 10 years for population growth to follow the money.... And these facts together explain the sort of bizarre fact that while again in the 19th century we left our ports... population growth has actually been faster around our old ports than it's been away from them-and it's not because everyone is working as a stevedore in the 21 st century. It's because those ports are the nuclei of those great metropolis areas that are so productive....

The success of our dense metropolitan areas, and the success even of our cities, over the past 20 years is something of a paradox. We live in an age in which it is effortless to electronically communicate across the planet... and yet, in so many ways, cities are more important, more vibrant, more productive than ever. We see this in the high-incomes of the urban areas I've just shown you; we see this in rising population levels in many urban areas. For the first decade since the 1870s, Boston grew faster than the state of Massachusetts over the last 10 years. And of course, we also see this in the housing prices; in the most productive areas, they've actually remained remarkably robust despite the national collapse.

This is even clearer in the developing world. Gandhi famously said, "The future of India is in its villages and not in its cities." But of course, the great man was wrong. The future of India is very much in its cities and places like Bangalore... There's the [example] of the Mindtree campus, which is very much the sort of new Bangalore. It's a place that is jam-packed full of smart software engineers and smart Indians who have come to be part of the magic of Bangalore. In any given day, the roof for lunch will be crammed full of workers connecting with each other and learning from each other, and it is also playing this role that cities have played for millennia—of being the connectors across oceans and continents, the connectors across civilizations. On any given day, you will see investors from Singapore and software moguls from Silicon Valley and even occasionally the socially awkward Harvard professor who wander in, connecting with Mindtree and being part of their experiment. Mindtree also reminds us of part of this paradox: you would think that software would be the industry above all that could benefit from long-distance communication. You would think that if any industry was going to be filled with people who would dial it in, it would be this industry. And yet, the most famous example of a geographic industrial cluster in the world today is Silicon Valley, where young people come to be part of the action...

The image of the world outside of Mindtree, the messy world of urban India... I think this reminds us that despite the enormous power and success of entrepreneurial private India, there still are enormous public failures. And as I think about the need for transportation research, the need for infrastructure development, the need for better land use understanding - the cities of the developing world are such an enormous challenge as we look forward. I think the most important thing that we face today is to make these cities livable as well as productive and enable them to play their role in terms of being places of global economic transformation. 
Over the course of the 19th century we built this tremendous network of canals and rails that enabled the vast wealth of the hinterlands to become accessible to the markets of the east, to the markets of Europe. And cities rose at pinch points along that network...And then, of course, industries formed around those transportation nodes, because those transportation nodes gave them an enormous advantage. Even when cities form for utterly prosaic reasons, like Armour's stockyards.... the combination of smart people in urban areas can often produce miracles—can produce the remarkable intellectual breakthroughs which have really made human civilization...

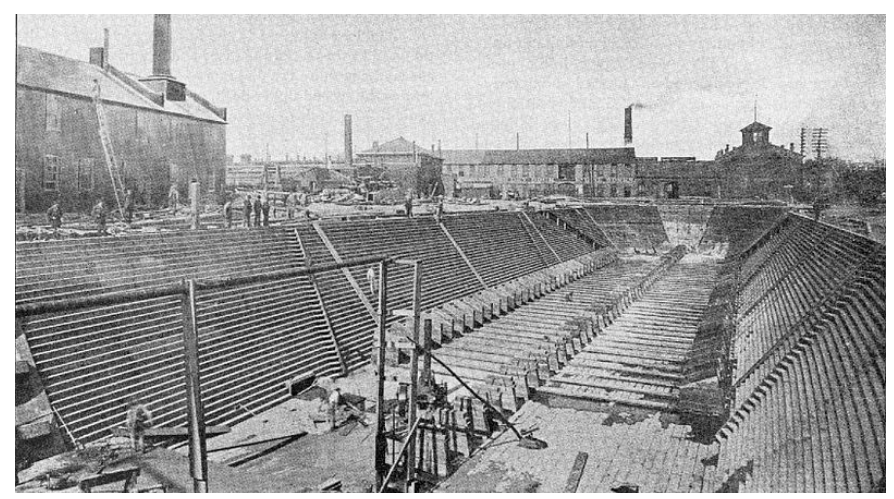

Detroit Dry Dock no 2 during construction, foot of Orleans St., 1892

This is an image of Detroit Dry Dock [Engine Works/Detroit Dry Dock Company], and you couldn't imagine a more natural industry to happen at a great inland port... Where else would you put a great innovative company that specialized in producing cutting-edge engines and cutting-edge ships for the inland water trade?

Detroit Dry Dock was also an incubator of engineering excellence, the place where the young Henry Ford works and learns about engineering before he goes off to work for Thomas Edison. Ford is, of course, the big name in Detroit but he's hardly the only name. There's a story that Ford followed Charles Kirby, the first person to build a car in Detroit, down the streets of Detroit on a bicycle, following his car, trying to figure out how that car worked. I can think of no better image of cities as places where ideas spread than Henry Ford pedaling furiously behind Kirby's car, trying to figure out how it operated. And of course, it's not just about Ford and Kirby, it's about the Dodge brothers, the Fischer brothers, David Dunbar Buick, Ransom Olds...a cascade of brilliant automobile manufacturers, all of whom were desperately trying to figure out the "new" new thing, all of them who had very close ties that were intellectual, that were related to supply, that were related to financing, and collectively they managed to come up with the mass-produced automobile. Of course, the automobile itself — the technology_was invented (despite what our president occasionally has said) in German cities, not in American cities, but we do deserve credit for the mass produced car. The great tragedy of Detroit... is that Ford's big idea was producing the car on a vast scale, in a vertically integrated factory walled off from the rest of the city. Successful cities in the 19th century, like successful cities today, are marked by three characteristics - small firms, smart people, and connections to the outside world. These things were true before Ford ever came to Detroit and they remain true across cities today. How far from that is the River Rouge, a vast vertically integrated factory that specializes in providing employment for less skilled Americans, and enabling them to be enormously productive doing the same thing over and over again-a great recipe for static productivity and turning out cheap cars and making them available on a vast scale, but a terrible recipe for urban reinvention and connection. Because once you've got this vertically integrated factory, it doesn't need the city, it doesn't contribute to the city. You might as well put it in the suburbs — and he did. You might as well move it to a lower-cost locale. And once conditions change—and they always do change-Detroit didn't have the stock that it needed to come back. This is one way of seeing what happened to Detroit and to the Rust Belt more generally. This is globalization over the 20th century-globalization, meaning the decline in the cost of moving goods.... So while in 1900, it was very valuable to locate a factory in Detroit because of those waterways and because of those rail yards, that edge that Detroit enjoyed, that edge that Cleveland enjoyed, that edge that Buffalo enjoyed, became largely irrelevant by the latter half of the 20th century.

And so manufacturing moved, first to the suburbs, then to the right-to-work states - the work of Tom Holmes at the University of Minnesota, which compares counties on rightto-work and non-right-to-work state borders, shows an enormous tendency of manufacturers to locate on the anti-union side of those borders - and of course, manufacturing moved to lower-cost areas more generally. That was always going to happen. But the questions was, which cities were actually able to come back and which ones were not?

One way to see what happened with the decline in transportation costs is that Americans were freed up to move to places they liked to live...And apparently, the thing that Americans really care about is warm Januarys. Because there's no variable that better predicts urban growth over the 20th century than January temperature... On top of the move to sun, these older cities like Detroit were hit by the move to sprawl. We have always built our urban spaces around the dominant transportation technology during the era which they're being created.... In the 20th century, we rebuilt the country around the car. Now some of that was always going to happen. The car was 
always going to be an attractive option for getting aroundthe average commute by car in America is 24 minutes and the average commute by public transportation is 48 minutes. And some of this was benighted federal policies that overly encouraged the move to suburbs.

The work by Nathanial Baum-Snow, which I'm a big fan of, shows us that each new highway that cut into a metropoli$\tan$ area reduced the central city's population by about 18 percent...I don't think that's an indictment of highways in some sort of wholesale manner. I'm a very strong believer that every form of transportation infrastructure needs to be taken on its own merits and actually evaluated by using rigorous tools of cost-benefit analysis and not just a general statement, but it certainly is true that for many years we didn't think very carefully about the full impact these developments would have. And we haven't thought very clearly about other policies, like our subsidies for home ownership, which are basically bribes to people to leave urban apartments. The consequence of the move to sun and sprawl was that these cities declined economically, and often social distress accompanied these declines... This was the picture of urban change between 1950 and 2000: 8 out of the 10 [largest cities in the U.S. in 1950] lost 20 percent of their population over the next 50 years, 3 out of the 10 lost 48 percent or more of their population, and Detroit lost another 25 percent of its population over the last 10 years alone. So this urban decline looks over in San Francisco and over in New York but it sure doesn't look over from the perspective of Detroit or Cleveland.

The federal government's strategies to stem urban decline were often of limited use.... I think the policy questions that these things bring up, and I'll just leave this out hanging, is that I see little case for the continuing federal obsession with home ownership... From the urban perspective, you're essentially bribing people to move out of urban apartments and into suburban homes, bribing them to own bigger homes, which typically tend to use more energy, and it's hard to see how that makes any sense in a world in which we have any worry whatsoever about climate change and carbon emissions.... While I have a very unnuanced view of the home mortgage interest deduction, transit policy is more complicated. I do see lots of areas for which federal supports for urban projects can make sense, but the price of federal transit support is often federal funding for highways. And it's not always obvious that once you have federal subsidies paying for local projects that you get the right local projects. That disconnect is a dangerous thing....

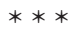

Now, while infrastructure was not associated with the comeback of these cities, some of the cities still did manage to come back, and their comeback was related far more to human capital than to physical capital, related to the fact that the same density that once got hogsheads onto clipper ships now speeds the flow of ideas... New York's comeback was associated with finance, which to a certain extent shouldn't surprise us, because there's no industry where new ideas are more valuable - where new knowledge is more valuable - than in finance...

There's also a sense in which New York experienced a chain in innovation in finance.... If you think about it there's something weird about trading floors. Here we have some of the wealthiest people on the planet, who in a normal industry would sit behind vast offices protected by oaken desks and oaken doors...enjoying all the perquisites of privacy that come with all that wealth. [On the trading floor] they're right on top of each other, they're sweating on top of each other, they're nudging into each other, they're foregoing all of that. And why? Because they need to know what's going on. They need to know what's happening around them. That makes them better traders, because that knowledge is so crucial. These trading floors...exist fundamentally because knowledge is more important than space. That is the city writ small. That's why New York came back. That's why Boston came back. And that is the resolution of our paradox that I started the talk with. What globalization and new technology have done is enabled some manufacturing firms to disperse, but they did something that was fundamentally more important than that. They increased the returns to being smart. They increased the returns to new ideas, because you can make it on the other side of the planet, because you can sell it on the other side of the planet....We have hundreds of papers now showing the rise in returns to skill, to knowledge over the last 30 years. Right now our greatest gift as a species is our ability to learn from people around us.

We come out of the womb with this remarkable set of talents to soak up information from our parents, from our peers...from everyone around us. Cities cater to that and make that happen. Face-to-face contact is not made irrelevant by new technologies-it's actually made more important. And there are two reasons why I think these new technologies have not eradicated the value of being close to each other. One reason is, the more complex the idea, the more important it is to be in the same room. Anyone who teaches knows the hard part of teaching is not actually knowing your script, it's knowing whether or not it's getting through... But there's another thing, which is that so much of what young people learn when they come to Silicon Valley, or come to New York, is completely unplanned....You have no idea what they're going to pick up. They're going to hang around and follow someone who is 
smarter than they are... and pick up the information needed to be successful.

\section{$* * *$}

Urban poverty is not a necessarily a sign of urban weakness. Cities don't make people poor. They attract poor people with the promise of economic activity, social services, and with the ability to get around without a car....There's nothing to be ashamed of that cities are attracting poor people. And there's nothing that suburbs should be proud of, in the sense that they aren't providing enough opportunities or housing or public transportation options for people with less resources....Any time you put large amounts of people on a small amount of land, there are enormous challenges. There are downsides of density. If two people are close enough to exchange an idea face to face, they are also close enough to exchange a contagious disease. For 3,000 years, cities have been dealing with the downsides of density — of contagious diseases, of crime, of congestion. I'm a Chicago Ph.D., and perhaps because of that I started my career with a proclivity toward laissez faire. But just as there is no such thing as an agnostic or an atheist in a manhole, I think there is no such thing as being a complete laissez faire person when you are actually dealing with the real problems of cities. Because, in fact, cities need management... The history of cities, and the future of cities... require forms of investment that actually make these cities more livable.

$* * *$

Some transportation problems require a purely engineering solution...Some problems, like congestion, don't. I think we believe now [that] vehicle miles traveled increase roughly one for one with highway miles built. It reminds us that we can't just build our way out of traffic congestion. And like all economists, I'm a big believer in that if you give away a valuable asset for free you're going to get long lines and stock outs...And yet, this is how too many cities run their transportation policies; they give away access to highways and city streets for free, and we have far too much usage. Singapore has done this for 36 years, and the second-densest country in the world has quickly moving streets because it prices them. I have no hope in the U.S. for more congestion fees except on new roads, but in the developing world, now is the time to advocate for this, when car ownership is low...If you build it in now, it will become part of the landscape, whereas if you build people's expectations that they'll always be able to drive on every road essentially for free, the history of the U.S. is that you're never getting out of it...Invest now in making this case even when it doesn't seem currently necessary.

When cities are able to manage the demons that come with density they become places of enormous pleasure as well as productivity. The same things that make cities productive can also make cities fun. And that's paying for the fixed costs of shared infrastructure, that's paying for the enabling industries that have large-scale economies, like theaters and museums to thrive, and I think most importantly, it's involving a tremendous amount of innovation and entrepreneurship... and just the sort of ordinary joys of connecting with other people.

The downside of cities succeeding as places of pleasure and productivity is that they can also become awfully expensive... We are shaping America with local land use policies that often are not very well thought out. And while this is costly in the U.S., it's tragic in Mumbai, it's tragic in the cities of India where much of central Mumbai has labored under a 1.33 FAR [floor area requirement] for the last 40 years. And while some high-rise buildings have been able to go up, often they need to be surrounded by green space to meet those FARs, which basically means there are no pedestrian areas that actually work. The result is tragic in the sense that this is a city that could be and should be housing many more people, and being much more affordable than it is....

The reason why this matters - not putting excessive barriers to building up-is because it's not about the U.S., but it's about China and India...Urban land use and transportation are so important because the pace of change there is so rapid and the ability to make huge mistakes is just enormous. But it's why it's so hopeful to me, because there's so much intellectual fire power in this room. Because it's only through the power of clear research, through cost-benefit analysis, through policies that don't restrict individual freedom, but that make sure people are making choices where they actually pay for the social costs of their actions-I think it's only through these policies that we get towards something that's a less dangerous, more hopeful world. 